\title{
Differential rejection of salmon lice by pink and chum salmon: disease consequences and expression of proinflammatory genes
}

\author{
Simon R. M. Jones ${ }^{1, *}$, Mark D. Fast ${ }^{2}$, Stewart C. Johnson ${ }^{2}$, David B. Groman ${ }^{3}$ \\ ${ }^{1}$ Pacific Biological Station, 3190 Hammond Bay Road, Fisheries and Oceans Canada, Nanaimo, British Columbia V9T 6N7, Canada \\ ${ }^{2}$ Institute for Marine Biosciences, National Research Council, 1411 Oxford Street, Halifax, Nova Scotia B3H 3Z1, Canada \\ ${ }^{3}$ Aquatic Diagnostic Services, Atlantic Veterinary College, University of Prince Edward Island, Charlottetown, \\ Prince Edward Island C1A 4P3, Canada
}

\begin{abstract}
The consequences of high (735 copepodids fish $\left.{ }^{-1}\right)$ and low (243 copepodids fish $\left.{ }^{-1}\right)$ level $^{2}$ exposures of size-matched juvenile pink and chum salmon to Lepeophtheirus salmonis copepodids were examined. At both levels of exposure the prevalence and abundance of L. Salmonis was significantly higher on chum salmon. In addition, the weight of exposed chum salmon following the high exposure was significantly less than that of unexposed chum salmon. At both exposures, the haematocrit of exposed chum salmon was significantly less than that of unexposed chum. Neither weight nor haematocrit of pink salmon was affected by exposures at these levels. Despite the presence of microscopic inflammatory lesions associated with attachment of L. salmonis on the epithelium of gill and fin of both salmon species, there were no mortalities following either exposure. A transient cortisol response was observed in chum salmon $21 \mathrm{~d}$ after low exposure. An earlier and quantitatively higher expression of the proinflammatory genes interleukin-8 (IL-8), tumour necrosis factor $\alpha-1$ (TNF $\alpha-1)$ and interleukin-1 $\beta$ (IL-1 $\beta$ ) in fin and head kidney of pink salmon suggested a mechanism of more rapid louse rejection in this species. Together, these observations indicate a relatively enhanced innate resistance to $L$. salmonis in the juvenile pink salmon compared with the juvenile chum salmon.
\end{abstract}

KEY WORDS: Oncorhynchus gorbuscha $\cdot$ Oncorhynchus keta $\cdot$ Lepeophtheirus salmonis $\cdot$ Sea lice · Immune response

Resale or republication not permitted without written consent of the publisher

\section{INTRODUCTION}

The salmon louse Lepeophtheirus salmonis (Krøyer) (Copepoda: Caligidae) occurs on adult Pacific salmon Oncorhynchus spp. in the mid-Pacific Ocean (Nagasawa et al. 1993, Nagasawa 2001) and in the coastal waters of British Columbia (BC) (Beamish et al. 2005). L. salmonis has recently been reported on pink salmon $O$. gorbuscha (Walbaum) and chum salmon O. keta (Walbaum) juveniles shortly after they enter nearshore waters (Morton et al. 2004). In the Atlantic Ocean, the parasite occurs on Atlantic salmon Salmo salar and sea trout $S$. trutta (Pike \& Wadsworth 1999). L. salmonis has a direct lifecycle that consists of 2 free-swimming nauplius stages, 1 free-swimming infectious copepodid stage, 4 attached chalimus stages, 2 preadult stages and a single adult stage (Johnson \& Albright 1991). With the exception of brief periods during the moults, the preadult and adult stages are free-moving on the host.

The susceptibility to infection and the development of disease following infection with Lepeophtheirus salmonis varies considerably among its hosts. Studies by Johnson \& Albright (1992), Johnson (1993), and Fast et al. (2002) have shown that naïve coho salmon Oncorhynchus kisutch, and chinook salmon O. tshawytscha and rainbow trout $O$. mykiss are less susceptible than naïve Atlantic salmon. In controlled singlespecies studies, heavily infected Atlantic salmon and 
sea trout have become moribund and died following louse development to the preadult and adult stages (Grimnes \& Jakobsen 1996, Finstad et al. 2000, Ross et al. 2000). The mechanisms of the innate immunity of coho and chinook salmon are poorly understood but may be associated with enhanced inflammation and epithelial cell hyperplasia at the site of infection (Johnson \& Albright 1992, Jones 2001). Under appropriate conditions, however, Pacific salmon are vulnerable to infection with $L$. salmonis, as demonstrated by the severity of lesions on heavily infected adult sockeye salmon O. nerka (Johnson et al. 1996).

The relative susceptibility to Lepeophtheirus salmonis and the consequences of infections on juvenile pink and chum salmon that have recently entered coastal habitats are not understood and few laboratory data are available. Recent observations showed that neither size nor condition factor of pink and chum salmon (ranging up to approximately $6 \mathrm{~g}$ ) were affected by natural infections with $L$. salmonis and another sea louse, Caligus clemensi (Jones \& Nemec 2004). Jones \& Nemec (2004) concluded haematological, physiological or behavioural data were required to better assess the impacts of sea lice infections. The purpose of the present study was to test the hypothesis of no differences in the effects of $L$. salmonis infection on juvenile pink and chum salmon. We compared the development of $L$. salmonis on laboratory-reared salmon and assessed the effects of infection on host size and survival, haematocrit, histological changes at attachment sites, cortisol response and expression of proinflammatory genes.

\section{MATERIALS AND METHODS}

Fish and tissue sampling. Pink and chum salmon were obtained as swim-up fry from the Quinsam River and Nanaimo River Hatcheries, respectively, on Vancouver Island, BC. The fish were reared in circular flow-through tanks containing 4201 of dechlorinated city water mixed equally with sand-filtered seawater. Salinity and temperature were monitored daily. The salmon were fed pelleted commercial salmon ration at a daily rate of approximately $1.5 \%$ body weight. They were acclimated to flowing seawater of $10^{\circ} \mathrm{C}$ and approximately $30 \%$ salinity following allocation to circular $33 \mathrm{l}$ tanks at least $7 \mathrm{~d}$ prior to exposure to copepodids.

Collection and culture of sea lice. Gravid female Lepeophtheirus salmonis were collected from adult sockeye (Trial 1) and chum (Trial 2) salmon freshly harvested from test fisheries. The lice were transported in ice-cold seawater to the laboratory, where dissected egg strings were incubated as described by Jones et al. (2006).
To initiate a challenge, flow to the 331 tanks was stopped, the volume reduced to 21 and supplemental aeration provided. Copepodids were added and flow resumed after $2 \mathrm{~h}$. Throughout the $2 \mathrm{~h}$ exposure all salmon were sedated by the addition of $0.15 \mathrm{mg} \mathrm{l}^{-1}$ metomidate.HCl (Syndel) to the tank water. Exposures to copepodids were conducted in darkness, and thereafter photoperiod was regulated at $10 \mathrm{~h}$ light: $14 \mathrm{~h}$ dark. All treatments, holding and sampling procedures used on unexposed control individuals were identical to those used on exposed individuals.

Experimental design. Two challenge trials were conducted. In the first (Trial 1), 8 tanks of 40 fish were established, 4 each of pink and chum salmon. Copepodids from the same hatching were added to 2 tanks of each species to a concentration of $243 \mathrm{fish}^{-1}$ (low exposure). Exposed and control salmon were sampled 7, 14, 21 and $28 \mathrm{~d}$ post-exposure (dpe). In Trial 2, 8 tanks of 10 salmon each were used, 4 each of pink and chum salmon as described above. Copepodids were added at a rate of $735 \mathrm{fish}^{-1}$ (high exposure), and exposed (4 tanks) and control (4 tanks) salmon were sampled 7 and 14 dpe.

Prior to sampling, all individuals in both trials were sedated as described above, then 10 were removed from each tank and killed by immersion in $300 \mathrm{mg} \mathrm{l}^{-1}$ tricaine methanesulphonate (Syndel). Sea lice on the body, fins and gills were counted and developmental stages determined for each fish. Differences in mean prevalence and abundance of Lepeophtheirus salmonis infections were considered statistically significant when $\mathrm{p}<0.05$ using $\chi^{2}$ and Mann-Whitney $U$-tests, respectively. Similarly, differences in the proportions of louse developmental stages were considered statistically significant when $p<0.05$ using the $\chi^{2}$ test. The length and weight of each fish was measured and blood collected into heparinated Caraway tubes (Fisher Scientific) from the severed caudal peduncle. Haematocrit was measured following 5 min centrifugation. Plasma was recovered from the centrifuged blood and stored at $-80^{\circ} \mathrm{C}$ for cortisol analysis. Right pelvic and pectoral fins (to assess gene expression in skin), liver, gills and head kidney were placed separately into RNAlater (Qiagen) and stored at $4{ }^{\circ} \mathrm{C}$ overnight, then at $-20^{\circ} \mathrm{C}$. Differences in mean weight and haematocrit were considered statistically significant when $\mathrm{p}<0.05$ determined using 2 -sample $t$-tests.

Histological analysis. Two gill arches, the left pectoral and pelvic fins, the dorsal and the caudal fins were collected 7 and $14 \mathrm{~d}$ after copepodid exposure in Trial 2 and fixed in neutral buffered 10\% formalin. Following routine histological processing, $5 \mu \mathrm{m}$ sections were stained with haematoxylin and eosin. A qualitative histopathological scoring system was adopted based on light microscopic examination of 
gill and fin samples. Scorings used were $0=$ normal (no ulceration and/or no inflammation of the integument); $1=$ mild ulceration and/or mild inflammation of the integument; $2=$ moderate ulceration and/or moderate inflammation of the integument; $3=$ severe ulceration and/or severe inflammation of the integument. Differences in mean scores were considered statistically significant when $\mathrm{p}<0.05$ using the Kruskal-Wallis test.

Isolation of RNA and cDNA synthesis. Approximately $50 \mathrm{mg}$ of each RNAlater-stabilised tissue were added to Trizol (900 $\mu \mathrm{l}$, Invitrogen) and macerated manually with a micro-tube pestle, or mechanically with $5 \mathrm{~mm}$ stainless steel beads (TissueLyser, Qiagen). Following $5 \mathrm{~min}$ incubation at $20^{\circ} \mathrm{C}$, chloroform (200 $\mu \mathrm{l}$, Sigma) was added and the homogenates mixed vigorously. After incubation at $20^{\circ} \mathrm{C}$ for $3 \mathrm{~min}$ the samples were centrifuged at $12272 \times g$ for $10 \mathrm{~min}$ at $5^{\circ} \mathrm{C}$. Equal volumes of the aqueous phase and molecular biological grade isopropyl alcohol (Sigma) were mixed, incubated for $5 \mathrm{~min}$, and the RNA pelleted at $12272 \times \mathrm{g}$ at $4^{\circ} \mathrm{C}$ for $5 \mathrm{~min}$. The pellet was washed with $750 \mu \mathrm{l}$ of $75 \%$ ethanol, air dried for $10 \mathrm{~min}$ and dissolved in $100 \mathrm{\mu l}$ molecular biology grade deionised formamide (Sigma) before storage at $-80^{\circ} \mathrm{C}$. Total RNA was measured using the NanoDrop-1000 Spectrophotometer (v3.2.1) and samples stored in $100 \%$ formamide at $-20^{\circ} \mathrm{C}$ for short-term storage ( 1 to $2 \mathrm{~d}$ ) and at $-80^{\circ} \mathrm{C}$ for longer periods ( $>2 \mathrm{~d}$ ). For reverse transcription, $1.5 \mu \mathrm{g}$ of total RNA from each sample was dissolved in molecular biological grade water. A 2-step reverse transcription-realtime quantitative polymerase chain reaction (qPCR) was carried out using the Superscript III qRT-PCR kit with SYBR green (Invitrogen) on an iCycler $\mathrm{iQ}^{\mathrm{TM}}$ Real-Time detection system (Bio-Rad). Following first strand synthesis, samples were stored at $-20^{\circ} \mathrm{C}$. Manufacturer's instructions were followed with the following exceptions: qPCR Mastermix was made up to $47.5 \mu \mathrm{l}$ (including $1.25 \mu \mathrm{l}$ of each primer) and $2.5 \mu \mathrm{l}$ of cDNA reaction was added for each sample and standard. The total volume of $50 \mu \mathrm{l}$ was then divided between 2 wells.

Real-time qPCR. The primers for qPCR were designed from previously published rainbow trout primers and from sequences conserved between rainbow trout and Atlantic salmon using Primer 3 software (Table 1) (Fast et al. 2006a,b). These primers have been used and validated for pink and chum salmon and cycling conditions followed those previously published (Fast et al. 2007). As 2 isoforms of interleukin-1 $\beta$ (IL-1 $\beta$ ) and tumor necrosis factor (TNF $\alpha$ ) are known to be present in rainbow trout, we designed primers in regions shown to be variable between $I L-1 \beta-1$ and $I L-1 \beta-2$, as well as $T N F \alpha-1$ and $T N F \alpha-2$. PCR products amplified from elongation factor $1 \mathrm{~A}(E F-1 A), I L-8, T N F \alpha-1$ and $I L-1 \beta-1$ were cloned into a TA-cloning vector $(\mathrm{pCR} 4-$ TOPO; Invitrogen) and the sequences confirmed. Plasmid vectors were isolated and used as standards for qPCR studies (Fast et al. 2006b).

To ensure genomic DNA was not quantified in qPCR experiments, EF-1A primers were designed to span an intron/exon splice site and single-product amplification was confirmed through melt curve analysis.

The sensitivity of reactions and amplification of contaminant products, such as primer dimers indiscriminately detected by SYBR green, were evaluated by amplifying duplicate 10 -fold dilutions of the cloned DNA (between 1 and $10^{-6} \mathrm{ng}$ ) and by performing a blank (no cDNA) in each run. The relationship between the threshold cycle $\left(C_{\mathrm{t}}\right)$ and the log (RNA) was linear $(-3.3<$ slope $<-3.1)$ for all reactions.

Table 1. Oncorhynchus gorbuscha and O. keta. Quantitative real-time PCR (qPCR) primer sets and cycling conditions. All qPCR experiments involved an initial $4 \mathrm{~min}\left(95^{\circ} \mathrm{C}\right)$ incubation prior to 40 cycles of denaturation $\left(30 \mathrm{~s} \mathrm{at} 95^{\circ} \mathrm{C}\right)$, annealing $(30 \mathrm{~s})$ and extension $\left(30 \mathrm{~s}\right.$ at $\left.72^{\circ} \mathrm{C}\right)$ periods as stated, followed by a final extension incubation of $5 \mathrm{~min}\left(72^{\circ} \mathrm{C}\right)$. Identity is expressed as percent identity to the same region of the same gene in rainbow trout. for: forward; rev: reverse

\begin{tabular}{|c|c|c|c|c|c|}
\hline \multirow[t]{2}{*}{ Genes } & \multirow[t]{2}{*}{ Primers } & \multirow[t]{2}{*}{ Sequences $\left(5^{\prime}-3^{\prime}\right)$} & \multirow{2}{*}{$\begin{array}{c}\text { Annealing } \\
\text { temperature }\left({ }^{\circ} \mathrm{C}\right)\end{array}$} & \multicolumn{2}{|c|}{ Product size and identity } \\
\hline & & & & Pink & Chum \\
\hline$\beta$-actin & $\begin{array}{l}\beta \text { actin }- \text { for } \\
\beta \text { actin }- \text { rev }\end{array}$ & $\begin{array}{l}\text { CAACTGGGACGACATGGAGA } \\
\text { AGTGAGCAGGACTGGGTGCT }\end{array}$ & 53 & $\begin{array}{l}88 \mathrm{bp} \\
(97 \%)\end{array}$ & $\begin{array}{l}88 \mathrm{bp} \\
(95 \%)\end{array}$ \\
\hline$E F-1 A$ & $\begin{array}{l}\text { EF-1A - for } \\
\text { EF-1A - rev }\end{array}$ & $\begin{array}{l}\text { GTGGAGACTGGAACCCTGAA } \\
\text { CTTGACGGACACGTTCTTGA }\end{array}$ & 53 & $\begin{array}{l}156 \mathrm{bp} \\
(94 \%)\end{array}$ & $\begin{array}{l}156 \mathrm{bp} \\
(91 \%)\end{array}$ \\
\hline$I L-1 \beta-1$ & $\begin{array}{l}\text { IL- } 1 \beta \text { - for } \\
\text { IL-1 } \beta \text {-rev }\end{array}$ & $\begin{array}{l}\text { CGTCACATTGCCAACCTCAT } \\
\text { ACTGTGATGTACTGCTGAAC }\end{array}$ & 58 & $\begin{array}{l}200 \mathrm{bp} \\
(99 \%)\end{array}$ & $\begin{array}{l}200 \mathrm{bp} \\
(97 \%)\end{array}$ \\
\hline$I L-8$ & $\begin{array}{l}\text { IL-8 - for } \\
\text { IL-8 - rev }\end{array}$ & $\begin{array}{l}\text { GAATGTCAGCCAGCCTTGTC } \\
\text { TCCAGACAAATCTCCTGACCG }\end{array}$ & 53 & $\begin{array}{l}226 \mathrm{bp} \\
(98 \%)\end{array}$ & $\begin{array}{l}226 \mathrm{bp} \\
(97 \%)\end{array}$ \\
\hline$T N F \alpha-1$ & $\begin{array}{l}\text { TNF } \alpha-\text { for } \\
\text { TNF } \alpha-\text { rev }\end{array}$ & $\begin{array}{l}\text { GGCGAGCATACCACTCCTCT } \\
\text { TCGGACTCAGCATCACCGTA }\end{array}$ & 58 & $\begin{array}{l}124 \mathrm{bp} \\
(98 \%)\end{array}$ & $\begin{array}{l}121 \mathrm{bp} \\
(99 \%)\end{array}$ \\
\hline
\end{tabular}


Elongation factor- $1 \alpha$ was chosen as the housekeeping gene for this study based on recent findings in Atlantic salmon (Moore et al. 2005, Olsvik et al. 2005). As $E F-1 A$ is expressed at constitutively higher levels than the cytokine genes studied here, all expression data are presented as mean ( \pm SEM) relative to $E F-1 A\left(E R E \times 10^{4}\right)$. Differences in gene expression were considered statistically significant when $\mathrm{p}<0.05$ using 1-way analysis of variance (ANOVA).

Cortisol measurements. Serum cortisol levels were determined by ELISA (Neogen) as previously described by Afonso et al. (2003). Briefly, serum samples were thawed on ice and then diluted 1:30 with the provided extraction buffer. The horseradish peroxidase conjugate $\left(120 \mu \mathrm{l}\right.$ plate $\left.^{-1}\right)$ was mixed with EIA buffer (Neogen) $(6.0 \mathrm{ml})$ and then added 1:1 (50 $\mu \mathrm{l}: 50 \mu \mathrm{l})$ with standards (ranging from 0.4 to $10 \mathrm{ng} \mathrm{ml}^{-1}$ ) and diluted samples (1:30) in the provided 96-well plate. All standards and samples were run in duplicate. The plate was gently shaken, covered and incubated at room temperature $\left(20^{\circ} \mathrm{C}\right)$ for $1 \mathrm{~h}$. The conjugate was removed and each well washed $3 \times$ with $250 \mu$ l of diluted wash buffer $\left(10 \% \mathrm{v} / \mathrm{v}\right.$ in $\left.\mathrm{ddH}_{2} \mathrm{O}\right)$. After removal of wash buffer, $150 \mu \mathrm{l}$ of K-Blue substrate (Neogen) was added to each well and the plate shaken gently. The plate was incubated at room temperature $\left(20^{\circ} \mathrm{C}\right)$ for $30 \mathrm{~min}$, shaken gently and the absorbance at $650 \mathrm{~nm}$ measured using a Spectromax 384 Plus Microplate Reader (Molecular Devices). Endpoint readings were determined using SoftMax Pro software (Version 4). Differences in mean cortisol were considered statistically significant when $\mathrm{p}<0.05$ using 1 -way ANOVA.
Table 2. Lepeophtheirus salmonis. Prevalence (Prev) and mean $( \pm \mathrm{SE})$ abundance (Abund) of parasites on juvenile pink and chum salmon following exposure to 243 (Trial 1) or 735 (Trial 2) copepodids fish $^{-1}$. $\mathrm{N}=$ sample size; ${ }^{*}$ significantly different from chum $\left(\mathrm{p}<0.01, \chi^{2}\right){ }^{*}{ }^{* *}$ significantly different from chum $(\mathrm{p}<0.01$, Mann-Whitney $U$-test)

\begin{tabular}{|c|c|c|c|c|c|c|}
\hline \multirow[t]{2}{*}{ Day } & \multicolumn{3}{|c|}{$\longrightarrow$ Pink -} & \multicolumn{3}{|c|}{ Chum } \\
\hline & $\mathrm{N}$ & Prev (\%) & ) Abund & $\mathrm{N}$ & Prev $(\%)$ & Abund \\
\hline \multicolumn{7}{|c|}{ Trial 1} \\
\hline 7 & 40 & 35.0 & $0.9 \pm 0.2$ & 40 & 55.0 & $1.3 \pm 0.3$ \\
\hline 14 & 30 & $16.7^{*}$ & $0.2 \pm 0.1^{* *}$ & 30 & 56.7 & $1.6 \pm 0.3$ \\
\hline 21 & 20 & $5.0^{*}$ & $0.1 \pm 0.1^{* *}$ & 20 & 55.0 & $1.3 \pm 0.4$ \\
\hline 28 & 10 & 10.0 & $0.1 \pm 0.1$ & 11 & 18.2 & $0.4 \pm 0.3$ \\
\hline \multicolumn{7}{|c|}{ Trial 2} \\
\hline 7 & 10 & 100 & $15.8 \pm 2.9$ & 10 & 100 & $26.2 \pm 3.9$ \\
\hline 14 & 10 & 100 & $6.6 \pm 1.9^{* *}$ & 10 & 100 & $15.6 \pm 2.8$ \\
\hline
\end{tabular}

the levels of lice on pink and chum salmon did not differ significantly. In Trial 2 (high exposure) in which the exposure level was 735 copepodids fish ${ }^{-1}$, abundances were significantly higher than in Trial 1 and lice were observed on all salmon examined 7 and 14 dpe (Table 2). At 7 dpe there was no significant difference in lice abundance between pink and chum salmon; however, by 14 dpe the abundance of lice was significantly lower on pink salmon (Table 2).

In Trial 1, Lepeophtheirus salmonis had developed to the adult stage by 21 dpe. There was no significant difference between pink and chum salmon in the proportions of louse developmental stages at any time following either low or high exposure (Table 3). Low numbers of lice were observed on chum salmon gills at both exposure levels but on pink salmon gills only at the high exposure level (Table 4).

\section{RESULTS}

\section{Sea lice infections}

Infections with Lepeophtheirus salmonis were established on pink and chum salmon in both trials. In the low exposure trial (243 copepodids fish ${ }^{-1}$ ) there was no significant difference in either prevalence or abundance of lice between pink and chum salmon at $7 \mathrm{~d}$ post-exposure (dpe) (Table 2). At the later sampling points the prevalence and abundance of L. salmonis declined on both host species, and at 14 and 21 dpe, prevalence and abundance were significantly lower on pink salmon (Table 2). At 28 dpe there were few lice remaining on the salmon and
Table 3. Lepeophtheirus salmonis. Percent of parasite developmental stages on juvenile pink and chum salmon following exposure to 243 (Trial 1) or 735 (Trial 2) copepodids fish ${ }^{-1} . \mathrm{N}=$ no. of lice; Co $=$ copepodid; I to IV $=1$ st to 4 th chalimus stages; $\mathrm{PA}=$ preadult; $\mathrm{Ad}=$ adult

\begin{tabular}{|c|c|c|c|c|c|c|c|c|c|}
\hline \multirow{2}{*}{ Day } & \multirow{2}{*}{ Fish } & \multirow{2}{*}{$\mathrm{N}$} & \multicolumn{5}{|c|}{ Developmental stage (\%) } & \multirow[b]{2}{*}{ PA } & \multirow[b]{2}{*}{ Ad } \\
\hline & & & $\mathrm{Co}$ & I & II & III & IV & & \\
\hline \multicolumn{10}{|c|}{ Trial 1} \\
\hline \multirow[t]{2}{*}{7} & Pink & 34 & 20.6 & 73.5 & 5.9 & & & & \\
\hline & Chum & 50 & 4.0 & 68.0 & 28.0 & & & & \\
\hline \multirow[t]{2}{*}{14} & Pink & 7 & & & 85.7 & 14.3 & & & \\
\hline & Chum & 41 & & 7.3 & 31.7 & 61.0 & & & \\
\hline \multirow[t]{2}{*}{21} & Pink & 2 & & & & & 50.0 & 50.0 & \\
\hline & Chum & 25 & & & & 4.0 & 24.0 & 16.0 & 56.0 \\
\hline \multirow[t]{2}{*}{28} & Pink & 1 & & & & & & & 100 \\
\hline & Chum & 4 & & & & & & & 100 \\
\hline \multicolumn{10}{|c|}{ Trial 2} \\
\hline \multirow[t]{2}{*}{7} & Pink & 158 & 45.6 & 54.4 & & & & & \\
\hline & Chum & 262 & 42.0 & 58.0 & & & & & \\
\hline \multirow[t]{2}{*}{14} & Pink & 66 & & & 15.2 & 80.3 & 4.5 & & \\
\hline & Chum & 156 & & 1.3 & 21.8 & 72.4 & 4.5 & & \\
\hline
\end{tabular}


Table 4. Lepeophtheirus salmonis collected from gills of lethally sampled salmon following exposure to 243 (Trial 1) or 735 (Trial 2) copepodids fish ${ }^{-1} . \mathrm{N}=$ no. of lice sampled; $\%=\%$ lice on gills

\begin{tabular}{|lrccc|}
\hline \multirow{2}{*}{ Day } & \multicolumn{2}{c}{ Pink } & \multicolumn{2}{c|}{ Chum } \\
& N & $\%$ & N & $\%$ \\
\hline Trial 1 & & & & \\
7 & 7 & 0 & 14 & 14.3 \\
14 & 2 & 0 & 13 & 0 \\
21 & 0 & 0 & 4 & 0 \\
28 & 1 & 0 & & \\
Trial 2 & & & 262 & 34.0 \\
7 & 158 & 37.3 & 156 & 15.4 \\
14 & 66 & 18.2 & & \\
\hline
\end{tabular}

\section{Size of fish}

There was no effect of low exposure on weight of juvenile pink salmon (exposed: $19.0 \pm 1.4 \mathrm{~g}$, unexposed: $20.4 \pm 1.7 \mathrm{~g}$ ) or chum salmon (exposed: $17.2 \pm$ $1.2 \mathrm{~g}$, unexposed: $19.3 \pm 0.9 \mathrm{~g}$ ). High exposure was, however, associated with a significantly lower weight of chum salmon at 14 dpe (exposed: $20.0 \pm 1.2 \mathrm{~g}$, unexposed: $24.6 \pm 1.7 \mathrm{~g}$ ) but was not associated with a significant difference in the weight of pink salmon (exposed: $20.4 \pm 2.3 \mathrm{~g}$, unexposed: $25.1 \pm 2.4 \mathrm{~g}$ ). There was no effect of low or high exposure on the condition factor of either salmon species.

\section{Histological changes}

Sea lice attachment lesions were characterised by inflammatory changes ranging from ulcerative necrosis, localised haemorrhage and fibrin deposition (Fig. 1) to a

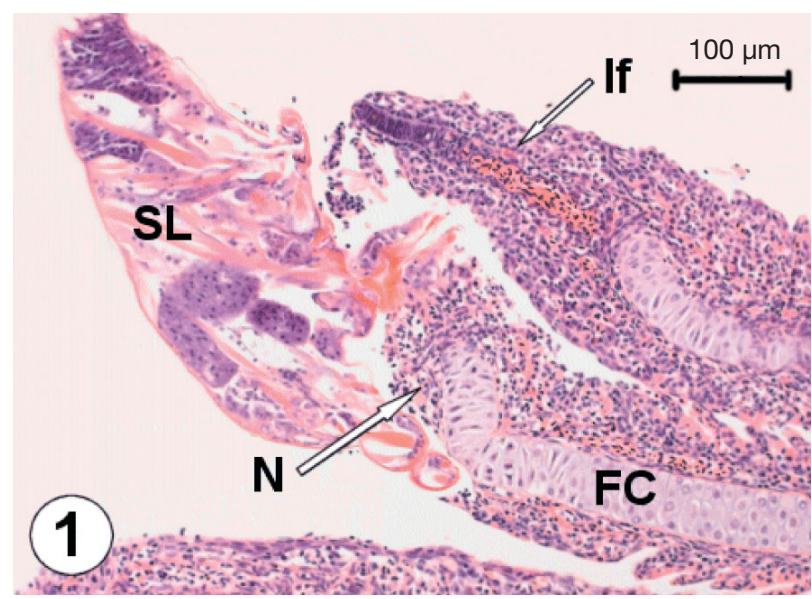

Fig. 1. Oncorhynchus gorbuscha infected with Lepeophtheirus salmonis. Section through gill filaments of pink salmon with attached L. salmonis chalimus I (SL). N = region of necrosis at site of attachment; If = mixed leucocyte infiltration of intralamellar epithelium; FC = gill filament cartilage. H\&E staining more generalised mucosal and subcuticular mixed leucocytic infiltration (Fig. 2) of affected gill mucosa and fin integument. The most severe lesions were observed on gill tissues where mean scores in $7 \mathrm{~d}$ samples were not different between exposed pink $(0.89 \pm 0.11)$ and chum $(1.22 \pm 0.15)$ salmon. Similarly, there were no differences between host species in mean lesion scores of dorsal fin $(0.70 \pm 0.15$ and $0.40 \pm 0.16$, respectively) or caudal fin $(0.10 \pm 0.10$ and $0.20 \pm 0.13$, respectively). By 14 dpe the gill lesions were no longer evident on exposed pink salmon and were significantly reduced on chum salmon $(0.40 \pm 0.16)$. Between 7 and 14 dpe there was no significant change in the mean score of lesions on dorsal or caudal fins on either species.

\section{Haematocrit}

Neither low nor high exposure had an effect on the mean haematocrit of pink salmon (Fig. 3). In contrast, $21 \mathrm{~d}$ after low exposure, the mean haematocrit of chum salmon was significantly lower than that of nonexposed chum salmon; 7 and $14 \mathrm{~d}$ after high exposure, the mean haematocrit of chum salmon was significantly lower than that of non-exposed chum salmon (Fig. 3).

\section{Plasma cortisol}

Mean plasma cortisol values ranged from 11.6 to $15.8 \mathrm{ng} \mathrm{ml}^{-1}$ in low-exposed pink salmon and from 1.4 to $10.0 \mathrm{ng} \mathrm{ml}^{-1}$ in non-exposed controls, without significant trends. In contrast, mean plasma cortisol was significantly higher in chum salmon, $21 \mathrm{~d}$ after low

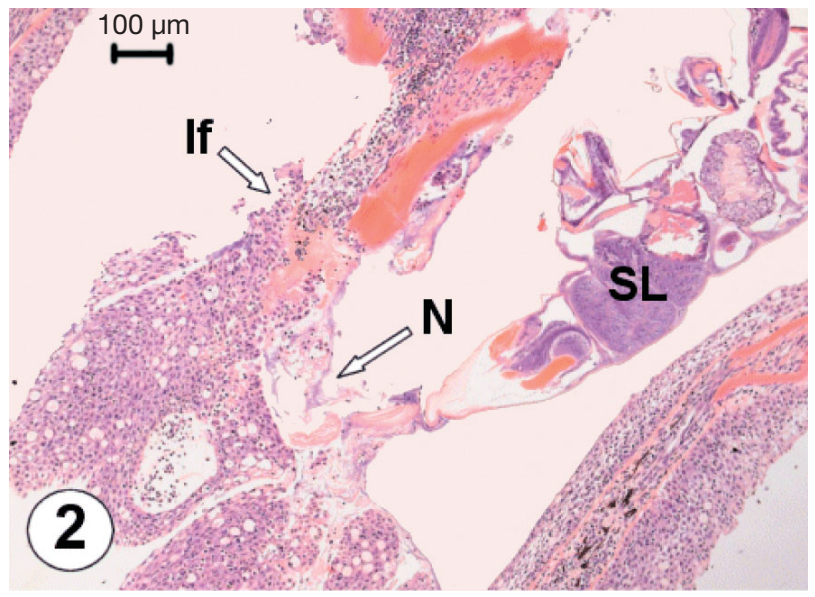

Fig. 2. Oncorhynchus gorbuscha infected with Lepeophtheirus salmonis. Histologic section through dorsal fin of pink salmon with attached L. salmonis chalimus III (SL). $\mathrm{N}=$ region of necrosis at attachment site; If $=$ region of integumental mixed leucocytic inflammation and hemorrhage. H\&E staining 


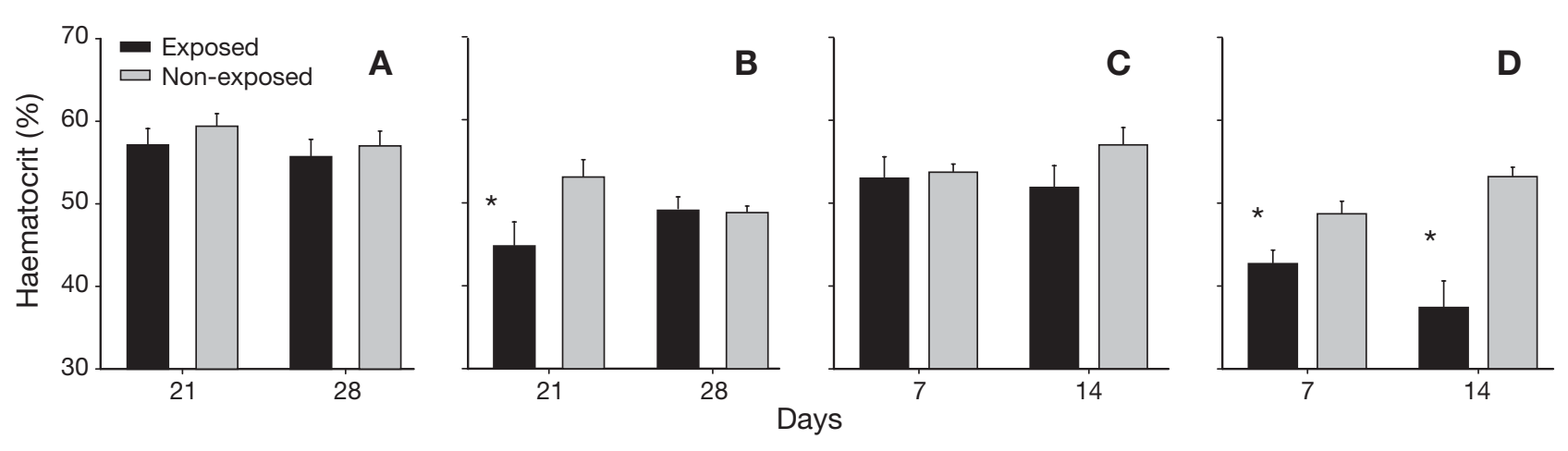

Fig. 3. Oncorhynchus gorbuscha and O. keta infected with Lepeophtheirus salmonis. Mean (+SE) haematocrit of (A,C) pink and $(B, D)$ chum salmon following exposure to (A,B) 243 or (C,D) 735 copepodids fish $^{-1}$. * Statistically significant difference between exposed and non-exposed salmon $(\mathrm{p}<0.05, t$-test, $\mathrm{n}=10)$

exposure compared with any other group and sample time (Fig. 4). Mean plasma cortisol in high-exposed pink and chum salmon ranged from 8.5 to $14.2 \mathrm{ng} \mathrm{ml}^{-1}$ and in controls, from 6.4 to $26.1 \mathrm{ng} \mathrm{ml}^{-1}$. Significant trends were not evident.

\section{Proinflammatory gene expression}

Individual variation in EF-1A expression was observed in both pink salmon (3.18 to $5.78 \times 10^{6}$ copies $\mu \mathrm{g}^{-1}$ total RNA) and chum salmon (3.34 to $4.32 \times 10^{6}$ copies $\mu^{-1}$ total RNA) kidney samples. Some variation was also observed in pink salmon $\left(2.91\right.$ to $3.99 \times 10^{6}$ copies $\mu^{-1}$ of total RNA) and chum salmon (2.14 to $2.56 \times 10^{6}$ copies $\mu g^{-1}$ of total RNA) fin (skin) samples; however, variation between tissues and species was no greater than that observed between individuals (data not shown). Expression in kidney was examined in both trials whereas expression in fins was only examined following low exposure (Trial 1).

A significant expression of $I L-8$ in pink salmon fins relative to that of EF-1A (ERE), was detected $7 \mathrm{~d}$ after low exposure, and in head kidney $7 \mathrm{~d}$ after high exposure (Fig. 5). There was no effect of low exposure on expression in chum salmon fins (20.9 to 127.7 ERE). Similarly, there was no effect of high exposure on the expression of $I L-8$ in chum salmon head kidney (2.8 to $7.8 \mathrm{ERE}$ ).

A significant expression of TNF $\alpha-1$ was detected in pink salmon head kidney 21 and $28 \mathrm{~d}$ following low exposure, and in chum salmon head kidney after 28 dpe (Fig. 6). Expression was significantly reduced in chum salmon kidney after 21 dpe (Fig. 6). Expression in exposed pink salmon head kidney at 21 and 28 dpe was significantly

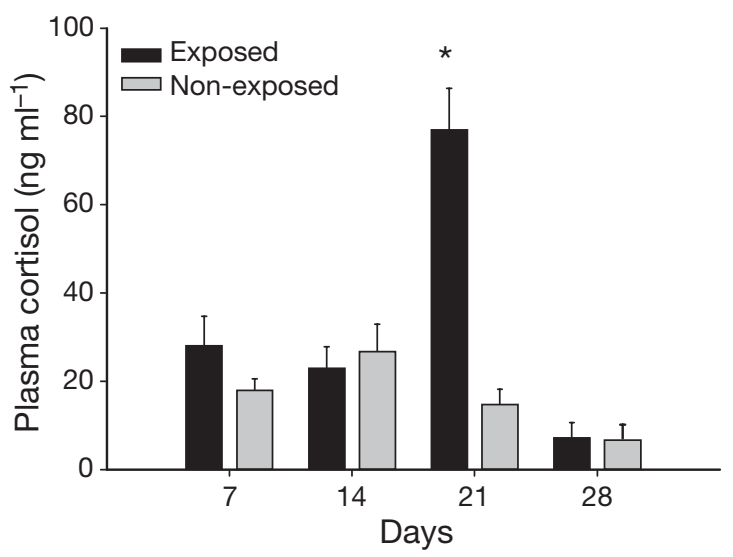

Fig. 4. Oncorhynchus keta infected with Lepeophtheirus salmonis. Mean (+SE) plasma cortisol of chum salmon following exposure to 243 copepodids fish ${ }^{-1}$. * Statistically significant difference between exposed and non-exposed salmon $(\mathrm{p}<0.05,1$-way ANOVA, $\mathrm{n}=10)$
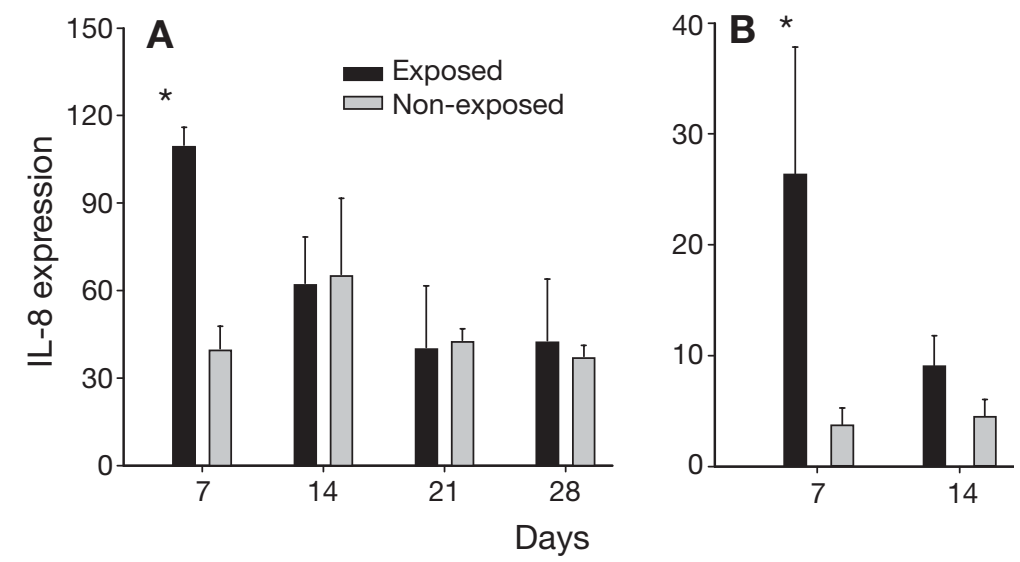

Fig. 5. Oncorhynchus gorbuscha infected with Lepeophtheirus salmonis. Mean (+SE) expression of interleukin-8 $(I L-8)$ relative to elongation factor $1 \mathrm{~A}(E F-1 A)$ in salmon tissues. (A) Fin of pink salmon at intervals after exposure to 243 copepodids fish ${ }^{-1}$; (B) head kidney of pink salmon at intervals after exposure to 735 copepodids fish ${ }^{-1}$. ${ }^{*}$ Statistically significant difference $(\mathrm{p}<0.05,1$-way ANOVA, $\mathrm{n}=10)$ 

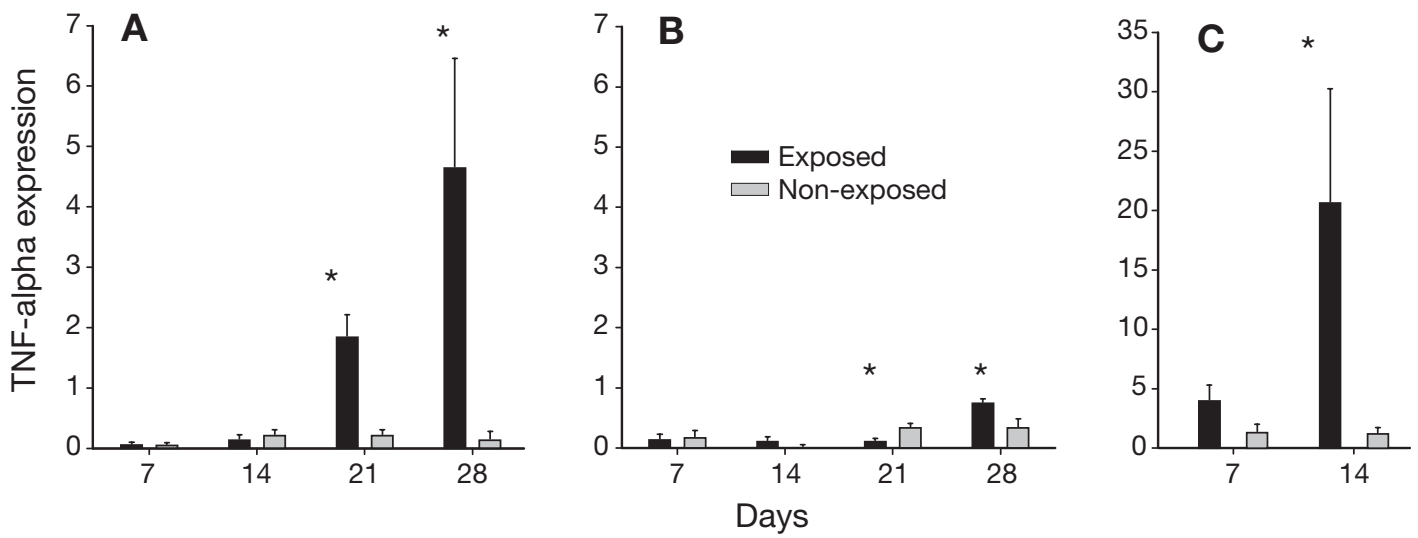

Fig. 6. Oncorhynchus gorbuscha and O. keta infected with Lepeophtheirus salmonis. Mean (+ SE) expression of tumour necrosis factor $(T N F) \alpha-1$ relative to elongation factor 1A $(E F-1 A)$ in salmon tissues. (A) Pink salmon head kidney following exposure to 243 copepodids fish $^{-1}$; (B) chum salmon head kidney following exposure to 243 copepodids fish $^{-1}$; (C) pink salmon head kidney following exposure to 735 copepodids. * Statistically significant difference $(\mathrm{p}<0.05,1$-way ANOVA, $\mathrm{n}=10)$

higher than in concurrently sampled exposed chum salmon head kidney. Expression of TNF $\alpha-1$ in fins of pink and chum salmon was not affected by low exposure and ranged from 0.13 to $0.48 \mathrm{ERE}$ and from 0.003 to $0.76 \mathrm{ERE}$, respectively. A significant expression of $T N F \alpha-1$ was detected in head kidney of pink salmon, $14 \mathrm{~d}$ after high exposure (Fig. 6). There was no effect of high exposure on the expression of $T N F \alpha-1$ in chum salmon head kidney (1.04 to $3.50 \mathrm{ERE}$ ).

A significant expression of $I L-1 \beta-1$ was detected in chum salmon fins $28 \mathrm{~d}$ following low exposure (Fig. 7). Expression in pink salmon fins and in the head kidney of pink and chum salmon was not affected by low exposure (9.5 to $36.7 \mathrm{ERE}, 16.9$ to $68.9 \mathrm{ERE}$ and 0.2 to 19.6 ERE, respectively). Similarly, there was no significant effect of high exposure on expression in head kidney of pink and chum salmon (8.3 to $16.0 \mathrm{ERE}$ and

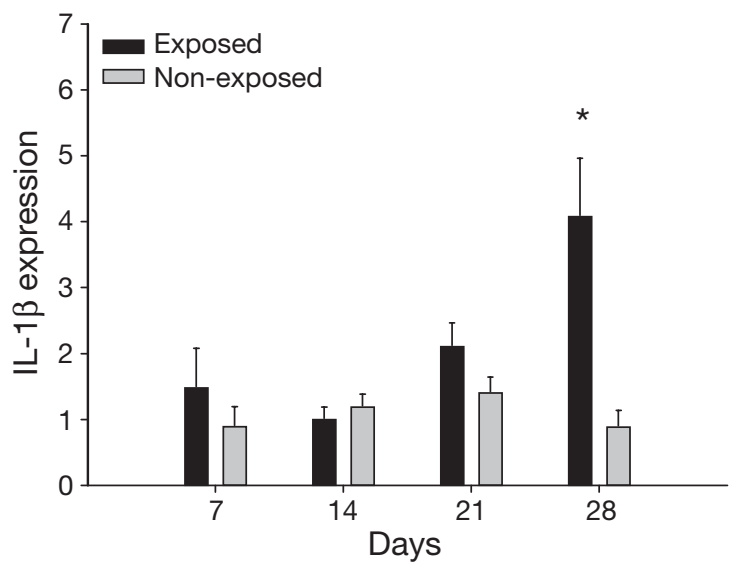

Fig. 7. Oncorhynchus keta infected with Lepeophtheirus salmonis. Mean $(+\mathrm{SE})$ expression of interleukin-1 $\beta(I L-1 \beta)$ relative to elongation factor $\mathrm{A}(E F-1 A)$ in exposed (exposure to 243 copepodids fish ${ }^{-1}$ ) and unexposed samples of left pectoral fin of chum salmon fin. * Statistically significant difference $(\mathrm{p}<0.05,1$-way ANOVA, $\mathrm{n}=10)$
0.4 to 1.0 ERE, respectively). The mean constitutive expression of $I L-1 \beta-1$ in unexposed pink salmon fins (range 9.5 to 36.6 ERE) was significantly higher than in chum salmon fins (range 0.4 to $1.4 \mathrm{ERE}$ ).

\section{DISCUSSION}

The key finding of this paper was the significantly different pattern of Lepeophtheirus salmonis infection on juvenile pink and chum salmon from Quinsam River and Nanaimo River stocks, respectively. The prevalence and abundance of lice on pink salmon were consistently lower than on chum salmon following low (243 copepodids fish ${ }^{-1}$ ) or high (735 copepodids fish ${ }^{-1}$ ) exposures. In addition, mean weight and haematocrit of exposed chum salmon were significantly lower than in unexposed chum whereas in pink salmon, weight and haematocrit were unaffected by exposure to $L$. salmonis. Together, these observations suggest differences in the innate resistance of juvenile pink and chum salmon to L. salmonis.

This Lepeophtheirus salmonis challenge model was previously used to compare infections on juvenile chum and pink salmon and threespine sticklebacks Gasterosteus aculeatus (Jones et al. 2006). In the earlier study, the prevalence and abundance of $L$. salmonis following experimental infection was significantly different among hosts, being greatest on sticklebacks followed by chum and then pink salmon. Seven-day louse survival, (lice fish $^{-1}$ at 7 dpe) (copepodids fish ${ }^{-1}$ in challenge $)^{-1} \times 100 \%$, ranged from 0.5 to $3.1 \%$ on salmon and from 6.6 to $16.5 \%$ on sticklebacks (Jones et al. 2006). In the present study, $7 \mathrm{~d}$ louse survival on pink and chum salmon ranged from 0.4 to $3.6 \%$, respectively. An estimate of 5 to $11 \mathrm{~d}$ louse survival rates were calculated from earlier Atlantic 
salmon data (Bron et al. 1991, Grimnes \& Jakobsen 1996, Tucker et al. 2000a,b, Fast et al. 2002). In those studies, louse survival ranged from approximately 3 to $75 \%$ and varied inversely with fish weight. Based on the relationship with weight, predicted $7 \mathrm{~d}$ louse survival on Atlantic salmon, size-matched to the mean weight of fish used here $(18.9 \pm 0.7 \mathrm{~g})$, was approximately $76 \%$. Previous L. salmonis 7 d survival data from sea trout (Bjørn \& Finstad 1997, 1998) are more limited but also suggest high rates $(\sim 58 \%)$. This suggests that $L$. salmonis has a settlement rate and early survival that is considerably lower on juvenile pink and chum salmon compared with Atlantic salmon and sea trout. Fast et al. (2002) reported that 7 d survival of L. salmonis on coho salmon and rainbow trout was significantly lower than on Atlantic salmon. In another study, significantly fewer $L$. salmonis were found on coho compared to Atlantic salmon $5 \mathrm{~d}$ following laboratory exposures (Johnson \& Albright 1992). In the latter study, L. salmonis survival on coho salmon was also significantly lower than on Atlantic and chinook salmon 15 to 20 d after exposure to copepodids. A comparison of $L$. salmonis survival shortly after exposure may be a useful indirect method for assessing relative susceptibility to the parasite among hosts. The available data lead us to postulate that, when healthy, salmonids of the genus Oncorhynchus are relatively resistant to infections with L. Salmonis compared with members of the genus Salmo. The magnitude of this enhanced resistance appears to vary among the Pacific salmon and probably changes with age. The present study attempts to understand some of the mechanisms involved by comparing pink and chum salmon.

The severity of physiological and pathological impact varies directly with the intensity of infection and with the stage of sea louse development (see Boxaspen 2006). In the present study, relatively high louse abundances were consistently observed on chum salmon, coincident with reduced haematocrit and weight. In contrast, there was no reduction in weight or haematocrit among concurrently exposed pink salmon. A reduction in haematocrit among moribund Atlantic salmon 25 d after exposure to Lepeophtheirus salmonis has been reported (Grimnes \& Jakobsen 1996). Similarly, Bowers et al. (2000) reported reduced haematocrits among Atlantic salmon 3, 7, 14 and $21 \mathrm{~d}$ after exposure to L. salmonis. Of interest in the present work, gill infections were observed on chum salmon in both trials and on pink salmon only in Trial 2. For example, $21 \mathrm{~d}$ after the low exposure a significant reduction in haematocrit was observed in chum salmon on which $23 \%$ of all observed lice occurred on the gill as chalimus IV and preadult stages. At this time gill infections were not observed on pink salmon. Gill infections are frequently observed during laboratory infections with L. salmonis (Bron et al. 1991, Johnson \& Albright 1991, Tucker et al. 2000b). The importance of the gill as a site of natural infection is not well documented and this phenomenon has been described as an artefact of laboratory challenge (Bron et al. 1991). Despite the relatively delicate nature of branchial architecture, gill infection alone did not appear to explain the reduced haematocrit as the haematocrit was not reduced among high-exposed pink salmon with gill infections. This is supported by histopathological changes of similar severity in gill tissue from both species $7 \mathrm{~d}$ following high exposure.

The ability of the host to respond following exposure to infection can be compromised by the stress response. While it is possible that differences in stocking densities between the 2 trials may have influenced the outcomes, individuals in both species were similarly stocked and handled. Furthermore, most individuals of both species exhibited low plasma cortisol levels, well within ranges expected for salmonids (Sumpter et al. 1986, Waring et al. 1992). An inverse relationship between stocking density and resistance to vibriosis has been reported for coho salmon (Schreck et al. 1985); however, evidence for a relationship between stocking density and the stress response is less obvious (Schreck 1996). The increase in plasma cortisol observed in chum salmon $21 \mathrm{~d}$ following low exposure was similar to that observed in Atlantic salmon and sea trout coincident with Lepeophtheirus salmonis moult to the preadult stage (Bjørn \& Finstad 1998, Bowers et al. 2000). There was no evidence from the present study of a cortisol response in either species earlier than $21 \mathrm{~d}$ after the low exposure. Cortisol is known to modulate disease resistance in fish by acting directly or indirectly on leucocyte subpopulations (Schreck 1996). The role of a cortisol response in regulating subsequent defence responses against parasitic infections in salmonids, including the expression of pro-inflammatory genes as previously suggested (Holland et al. 2003), requires further investigation.

The expression of pro-inflammatory cytokine genes differed significantly between the salmon species following exposures to low or high numbers of copepodids. Notable was the expression of $I L-8$ only in pink salmon following both exposures. The expression of $I L-8$ has not previously been reported following exposure of salmonids to Lepeophtheirus salmonis. Similar to the present study, $I L-1 \beta-1$ and $T N F \alpha-1$ expression was previously detected, albeit inconsistently, in head kidney of Atlantic salmon following exposure to $L$. salmonis copepodids (Fast et al. 2006a,b). $I L-1 \beta-1$ has not previously been reported in the skin of salmon exposed to L. salmonis. Thus, our observations support the earlier work and suggest a role of $I L-8, I L-1 \beta-1$ and $T N F \alpha-1$ in the differential patterns of L. salmonis 
infestation observed on pink and chum salmon. In particular, as IL-8 is a potent neutrophil chemotactic factor, expression of this gene in pink salmon suggests a mobilisation of inflammatory cells to the site of infection, and therefore helps to explain the more rapid rejection of the parasite from this species. The inflammatory lesions in the gills and fins of exposed salmon of both species supports this suggestion as well as earlier work in which the role of epidermal inflammation and hyperplasia were described as part of the response of Oncorhynchus spp. to L. salmonis infestation (Johnson \& Albright 1992).

In other studies, infection with the ciliate Ichthyophthirius multifiliis resulted in increased expression of $I L-1 \beta-1, T N F \alpha-1$ and $I L-8$ genes in rainbow trout skin after $4 \mathrm{~d}$ (Sigh et al. 2004). Similarly, primary exposure to the monogenean Gyrodactylus derjavini was shown to elicit the early expression of $I L-1 \beta-1$ and $T N F \alpha-1$ genes in the skin of rainbow trout (Lindenstrøm et al. 2003 , 2004). Expression of $I L-8$ was not detected in the latter studies. A related study (Lindenstrøm et al. 2006) found elevated skin expression of $I L-1 \beta-1$ in a susceptible strain of Atlantic salmon Salmo salar but not in a resistant strain $2 \mathrm{wk}$ following exposure to G. salaris. These studies indicate that expression patterns of proinflammatory genes vary according to the hostparasite system.

Infection densities of Lepeophtheirus salmonis on pink salmon, and less so on chum salmon, are reduced more rapidly than has previously been observed in Atlantic salmon and sea trout, consistent with observations made on coho salmon (Johnson \& Albright 1992, Grimnes \& Jakobsen 1996, Bjørn \& Finstad 1997, Bowers et al. 2000, Fast et al. 2002). As in the present work, this loss of parasites was linked to a well-developed inflammatory response in coho salmon, and was histologically associated with neutrophil invasion of the attachment and feeding site shortly after infection (Johnson \& Albright 1992). Previous work has shown that the expression of $I L-1 \beta-1, T N F \alpha-1$ and $I L-8$ was upregulated in juvenile pink and chum salmon by $6 \mathrm{~h}$ following vaccination (Fast et al. 2007). In particular, expression of $I L-8$ was maintained for at least $24 \mathrm{~h}$ post vaccination. The expression of CXCa (an IL-8-like chemokine) and $I L-1$ in the skin of common carp Cyprinus carpio 2 to $3 \mathrm{~h}$ following mechanical trauma (Gonzalez et al. 2006) raises the possibility that our observations reflected a generalised response to skin damage and were not necessarily specific to the attachment of L. salmonis. Regardless of the stimulus, the rapid expression of proinflammatory cytokine genes suggests that in future studies, juvenile salmon should be sampled much sooner following exposure to L. salmonis copepodids to better understand species-specific patterns of response. In conclusion, pink salmon juve- niles responded to $L$. salmonis infection differently than size-matched chum salmon. In pink salmon, the responses of $I L-8$ and $T N F \alpha-1$, in concert with an elevated constitutive expression of $I L-1 \beta-1$, coincided with the elimination of most parasites. This pattern of parasite elimination occurred later in chum salmon, permitting further parasite development and clinical consequences (e.g. weight loss, anemia, ionic imbalance, etc.). Thus, the rapid response of pink salmon to the juvenile stages of $L$. salmonis appears to be an adaptation to avoid the clinical signs of disease associated with larger and mobile preadult and adult parasite stages.

Acknowledgements. The authors acknowledge the assistance of E. Kim, S. Dawe and G. Prosperi-Porta, DFO, Nanaimo, in maintaining salmon and processing tissues. Sequencing services were provided by Genome Atlantic. Dr. B. Nowak, University of Tasmania, kindly reviewed an earlier draft and provided critical comments. This research was funded by a grant from the British Columbia Innovation Council.

\section{LITERATURE CITED}

Afonso LOB, Basu N, Nakano K, Devlin RH, Iwama GK (2003) Sex-related differences in the organismal and cellular stress response in juvenile salmon exposed to treated bleached kraft mill effluent. Fish Physiol Biochem 29:173-179

Beamish RJ, Neville CM, Sweeting RM, Ambers N (2005) Sea lice on adult Pacific salmon in the coastal waters of central British Columbia, Canada. Fish Res 76:198-208

Bjørn PA, Finstad B (1997) The physiological effects of salmon lice infection on sea trout smolts. Nord J Freshw Res 73: 60-72

Bjørn PA, Finstad B (1998) The development of salmon lice (Lepeophtheirus salmonis) on artificially infected postsmolts of sea trout (Salmo trutta). Can J Zool 76:970-977

Bowers JM, Mustafa A, Speare DJ, Conboy GA, Brimacombe M, Sims DE, Burka JF (2000) The physiological response of Atlantic salmon, Salmo salar L., to a single experimental challenge with sea lice, Lepeophtheirus salmonis. J Fish Dis 23:165-172

Boxaspen K (2006) A review of the biology and genetics of sea lice. ICES J Mar Sci 63:1304-1316

Bron JE, Sommerville C, Jones M (1991) The settlement and attachment of early stages of the salmon louse, Lepeophtheirus salmonis (Copepoda: Caligidae) on the salmon host, Salmo salar. J Zool 224:201-212

Fast MD, Ross NW, Mustafa A, Sims DE and 5 others (2002) Susceptibility of rainbow trout Oncorhynchus mykiss, Atlantic salmon Salmo salar and coho salmon Oncorhynchus kisutch to experimental infection with sea lice Lepeophtheirus salmonis. Dis Aquat Org 52:57-68

Fast MD, Muise DM, Easy RE, Ross NW, Johnson SC (2006a) The effects of Lepeophtheirus salmonis infections on the stress response and immunological status of Atlantic salmon (Salmo salar). Fish Shellfish Immunol 21:228-241

Fast MD, Ross NW, Muise DM, Johnson SC (2006b) Differential gene expression in Atlantic salmon infected with Lepeophtheirus salmonis. J Aquat Anim Health 18:116-127

Fast MD, Johnson SC, Jones SRM (2007) Differential expression of the pro-inflammatory cytokines IL-1 $\beta-1$, TNF $\alpha-1$ 
and IL-8 in vaccinated pink (Oncorhynchus gorbuscha) and chum (Oncorhynchus keta) salmon juveniles. Fish Shellfish Immunol 22:403-407

Finstad B, Bjørn PA, Grimnes A, Hvidsten NA (2000) Laboratory and field investigations of salmon lice [Lepeophtheirus salmonis (Krøyer)] infestations on Atlantic salmon (Salmo salar L.) post-smolts. Aquac Res 31:795-803

Gonzalez SF, Huising MO, Rimantas S, Forlenza M, Verburgvan Kamenade BML, Buchmann K, Nielsen ME, Wiegertjes GF (2007) Real-time gene expression analysis in carp (Cyprinus carpio L.) skin: inflammatory responses to injury mimicking infection with ectoparasites. Dev Comp Immunol 31:244-254

Grimnes A, Jakobsen PJ (1996) The physiological effects of salmon lice infection on post-smolt of Atlantic salmon. J Fish Biol 48:1179-1194

Holland JW, Gould CRW, Jones CS, Noble LR, Secombes CJ (2003) The expression of immune-regulatory genes in rainbow trout, Oncorhynchus mykiss, during a natural outbreak of proliferative kidney disease (PKD). Parasitology 126:S95-S102

Johnson SC (1993) A comparison of development and growth rates of Lepeophtheirus salmonis (Copepoda: Caligidae) on naïve Atlantic (Salmo salar) and chinook (Oncorhynchus tshawytscha) salmon. In: Boxhall GA, Defaye D (eds) Pathogens of wild and farmed fish sea lice. Ellis Horwood, Chichester, p 68-80

Johnson SC, Albright LJ (1991) Development, growth, and survival of Lepeophtheirus salmonis (Copepoda: Caligidae) under laboratory conditions. J Mar Biol Assoc UK 71:425-436

Johnson SC, Albright LJ (1992) Comparative susceptibility and histopathology of the response of naïve Atlantic, chinook and coho salmon to experimental infection with Lepeophtheirus salmonis (Copepoda: Caligidae). Dis Aquat Org 14:179-193

Johnson SC, Blaylock RB, Elphink J, Hyatt KD (1996) Disease induced by the sea louse (Lepeophtheirus salmonis) (Copepoda: Caligidae) in wild sockeye salmon (Oncorhynchus nerka) stocks of Alberni Inlet, British Columbia. Can J Fish Aquat Sci 53:2888-2897

Jones SRM (2001) The occurrence and mechanisms of innate immunity against parasites in fish. Dev Comp Immunol 25:841-852

Jones SRM, Nemec A (2004) Pink salmon action plan: sea lice on juvenile salmon and some non-salmonid species in the Broughton Archipelago in 2003. Canadian Science Advisory Secretariat Research Document 2004/105. Fisheries and Oceans Canada, Nanaimo

Jones SRM, Kim E, Dawe S (2006) Experimental infections with Lepeophtheirus salmonis (Krøyer) on threespine sticklebacks, Gasterosteus aculeatus L. and juvenile Pacific salmon, Oncorhynchus spp. J Fish Dis 29:489-495

Lindenstrøm T, Buchmann K, Secombes CJ (2003) Gyrodactylus derjavini infection elicits $\mathrm{Il}-1 \mathrm{~B}$ expression in rainbow trout skin. Fish Shellfish Immunol 15:107-115

Lindenstrøm T, Secombes CJ, Buchmann K (2004) Expression of immune response genes in rainbow trout skin induced by Gyrodactylus derjavini infections. Vet Immunol Immunopathol 97:137-148

Lindenstrøm T, Sigh J, Dalgaard MB, Buchmann K (2006)

Editorial responsibility: Robin Overstreet,

Ocean Springs, Mississippi, USA
Skin expression of IL-1 $\beta$ in East Atlantic salmon, Salmo salar L., highly susceptible to Gyrodactylus salaris infection is enhanced compared to a low susceptibility Baltic stock. J Fish Dis 29:123-128

Moore LJ, Somamoto T, Lie KK, Dijkstra JM, Hordvik I (2005) Characterisation of salmon and trout CD8a and CD8b. Mol Immunol 42:1225-1234

Morton A, Routledge R, Peet C, Ladwig A (2004) Sea lice (Lepeophtheirus salmonis) infection rates on juvenile pink (Oncorhynchus gorbuscha) and chum (Oncorhynchus keta) salmon in the nearshore marine environment of British Columbia, Canada. Can J Fish Aquat Sci 61:147-157

Nagasawa K (2001) Annual changes in the population size of the salmon louse Lepeophtheirus salmonis (Copepoda: Caligidae) on high-seas Pacific salmon (Oncorhynchus spp.), and relationship to host abundance. Hydrobiologia 453/454:411-416

Nagasawa K, Ishida Y, Ogura M, Tadokoro K, Hiramatsu K (1993) The abundance and distribution of Lepeophtheirus salmonis (Copepoda: Caligidae) on six species of Pacific salmon in offshore waters of the north Pacific Ocean and Bering Sea. In: Boxhall GA, Defaye D (eds) Pathogens of wild and farmed fish sea lice. Ellis Horwood, Chichester, p 166-178

Olsvik PA, Lie KK, Jordal AEO, Nilsen TO, Hordvik I (2005) Evaluation of potential reference genes in real-time RTPCR studies of Atlantic salmon. BioMed Central Mol Biol 6:21-30

Pike AW, Wadsworth SL (1999) Sealice on salmonids: their biology and control. Adv Parasitol 44:233-337

Ross NW, Firth KJ, Wang A, Burka JF, Johnson SC (2000) Changes in hydrolytic enzyme activities of naive Atlantic salmon Salmo salar skin mucus due to infection with the salmon louse Lepeophtheirus salmonis and cortisol implantation. Dis Aquat Org 41:43-51

Schreck CB (1996) Immunomodulation: endogenous factors. In: Iwama G, Nakanishi T (eds) The fish immune system: organism, pathogen and environment. Academic Press, San Diego, CA, p 311-337

Schreck CB, Patino R, Pring CK, Winton JR, Holway JE (1985) Effects of rearing density on indices of smoltification and performance of coho salmon, Oncorhynchus kisutch. Aquaculture 44:345-358

Sigh J, Lindenstrom T, Buchmann K (2004) Expression of proinflammatory cytokines in rainbow trout (Oncorhynchus mykiss) during an infection with Ichthyophthirius multifiliis. Fish Shellfish Immunol 17:75-86

Sumpter JP, Dye HM, Benfey TJ (1986)The effects of stress on plasma ACTH, $\alpha-\mathrm{MSH}$, and cortisol levels in salmonid fishes. Gen Comp Endocrinol 62:377-385

Tucker, CS, Sommerville C, Wootten R (2000a) An investigation into the larval energetics and settlement of the sea louse, Lepeophtheirus salmonis, an ectoparasitic copepod of Atlantic salmon, Salmo salar. Fish Pathol 35:137-143

Tucker CS, Sommerville C, Wootten R (2000b) The effect of temperature and salinity on the settlement and survival of copepodids of Lepeophtheirus salmonis (Krøyer, 1837) on Atlantic salmon, Salmo salar L. J Fish Dis 23:309-320

Waring CP, Stagg RM, Poxton MG (1992) The effects of handling on flounder (Platichthys flesus L.) and Atlantic salmon (Salmo salar L.). J Fish Biol 41:131-144

Submitted: November 16, 2006; Accepted: December 29, 2006 Proofs received from author(s): April 11, 2007 